\title{
HER2/neu overexpression in the development of muscle-invasive transitional cell carcinoma of the bladder
}

\author{
Z Latif', AD Watters', I Dunn', KM Grigor², MA Underwood' and JMS Bartlett*,I \\ 'University Department of Surgery, Level II, Queen Elizabeth Building, Glasgow Royal Infirmary, Glasgow G3I 2ER, UK; 'niversity Department of \\ Pathology, Western General Hospital, Edinburgh EH4 2XU, UK
}

\begin{abstract}
The mortality from transitional cell carcinoma (TCC) of the urinary bladder increases significantly with the progression of superficial or locally invasive disease ( $\mathrm{pTa} / \mathrm{pTI})$ to detrusor muscle-invasive disease $(\mathrm{pT} 2+)$. The most common prognostic markers in clinical use are tumour stage and grade, which are subject to considerable intra- and interobserver variation. Polysomy 17 and HER2/neu gene amplification and protein overexpression have been associated with more advanced disease. Standardised techniques of fluorescence in situ hybridisation and immunohistochemistry, which are currently applied to other cancers with a view to offering antiHER2/neu therapies, were applied to tumour pairs comprising pre- and postinvasive disease from 25 patients undergoing treatment for bladder cancer. In the preinvasive tumours, increased HER2/neu copy number was observed in $76 \%$ of cases and increased chromosome 17 copy number in $88 \%$ of cases, and in the postinvasive group these values were 92 and $96 \%$, respectively (not significantly different $P=0.09$ and 0.07 , respectively). HER2 gene amplification rates were $8 \%$ in both groups. Protein overexpression rates were 76 and $52 \%$, respectively, in the pre- and postinvasive groups $(P=0.06)$. These results suggest that $H E R 2 / n e u$ abnormalities occur prior to and persist with the onset of muscle-invasive disease. Gene amplification is uncommon and other molecular mechanisms must account for the high rates of protein overexpression. Anti-HER2/neu therapy might be of use in the treatment of TCC.

British Journal of Cancer (2003) 89, I305-1309. doi:I0.1038/sj.bjc.660 I 245 www.bjcancer.com

(c) 2003 Cancer Research UK
\end{abstract}

Keywords: transitional cell carcinoma; oncogenes; HER2/neu

Transitional cell carcinoma (TCC) of the urinary bladder is common in the UK, with over 15000 new cases being diagnosed annually. The low mortality from superficial disease contributes to this being the second most prevalent cancer in the UK population. However, with the development of detrusor muscle invasion, mortality rates increase significantly, and over $50 \%$ of patients already have micrometastasis on diagnosis of detrusor muscleinvasive disease. Therefore, more aggressive clinical treatment needs to be applied, if there is a curative aim, in the form of radical surgery or radiotherapy plus adjuvant treatment (Skinner et al, 1991). Approximately $10-15 \%$ of superficial or locally invasive (pTa/pT1) tumours progress to muscle invasion, and this risk is dependent on tumour stage and grade. For example, welldifferentiated (grade 1) tumours progress in only $2 \%$ of cases, whereas poorly differentiated (grade 3 ) tumours progress in up to $20 \%$ of cases. However, stage and grade are subject to $50 \%$ interand intraobserver variation (van der Meijden et al, 2000).

\footnotetext{
*Correspondence: Dr JMS Bartlett, Endocrine Cancer Group, Surgical and Translational Research Section, Division of Cancer and Molecular Pathology, University of Glasgow, Department of Surgery, Level II, Queen Elizabeth Building, Glasgow Royal Infirmary, Glasgow G3I 2ER, UK; E-mail: j.m.bartlett@clinmed.gla.ac.uk

Received 7 February 2003; revised 25 June 2003; accepted 8 January 2003
}

Therefore, more accurate prognostic factors are desirable, and genetic markers might fulfil this role (Reznikoff et al, 2000).

Polysomy 17 in TCC is a chromosome-specific event, independent of tumour polyploidy (Bartlett et al, 1999) and is associated with higher tumour stages and grades as well as disease recurrence, progression and decreased patient survival (Bartlett et al, 1998; Li et al, 1998; Watters et al, 2000). Polysomy 17 has been observed in $10 \%$ of grade 1 and $43 \%$ of grade 3 tumours (Watters et al, 2000) and $32 \%$ of $\mathrm{pTa} / \mathrm{T} 1$ and $72 \%$ of pT2 tumours (Li et al, 1998). Gain of chromosome 17 may therefore be a useful marker of tumour progression.

The HER2/neu oncogene is located on chromosome 17 q11-21 and encodes for a tyrosine kinase trans-membrane growth factor receptor. Activation of the HER2/neu receptor, following autophosphorylation of the tyrosine kinase residues results in the activation of a cascade of intracellular proteins. Ultimately, the mitotic activity and metastatic potential of the cell increases (Underwood et al, 1995; Tzahar et al, 1996; Olayioye et al, 2000).

HER2/neu protein overexpression, assessed by immunohistochemistry (IHC), has been associated with increased tumour grade in TCC, but there is a wide variation in the literature of $2-50 \%$ (Wright et al, 1990; Coombs et al, 1991; McCann et al, 1990; Underwood et al, 1995; Mellon et al, 1996). This may be due to the application of different antibodies and scoring systems. Similarly, although HER2/neu gene amplification rates are higher in muscleinvasive disease compared with superficial disease, there is a wide variation in the literature of $4-32 \%$ (Coombs et al, 1991; 
Underwood et al, 1995; Mellon et al, 1996). Accurate assessment of the prognostic significance of HER2 in the progression of bladder cancer requires standardisation of the laboratory techniques. Current UK guidelines recommend the use of IHC, with the use of specific antibodies and scoring systems to assess protein overexpression, and fluorescence in situ hybridisation (FISH) to assess gene amplification. Our centre is one of the designated centres in the UK that has the facilities to apply such techniques (Ellis et al, 2000). This is particularly important if the HER2/neu oncogene is to be targeted with one of the various anti-HER2/neu therapies being used in the treatment of other cancers. In breast cancer, tumours that have evidence of HER2/neu gene amplification, or strong protein overexpression respond to treatment with the antiHER2/neu monoclonal antibody Trastuzumab (Herceptin, Gnenetech Inc San Francisco, USA). Response rates of $50 \%$ have been observed in combination with chemotherapy and $26 \%$ as monotherapy in women with metastatic breast cancer as well as an increased time to progression (Slamon et al, 2001; Vogel et al, 2001).

The aim of the present study was to assess HER2/neu protein overexpression and gene amplification in 25 tumour pairs. The first tumour of the pair was pre (muscle) invasive and the second tumour (from the same patient) was postinvasive.

\section{MATERIALS AND METHODS}

\section{Patients}

Patients with tumours that had progressed from superficial disease (pTa/pT1) to muscle-invasive disease (pT2) were identified from a bladder cancer database in the Department of Surgery, Glasgow Royal Infirmary. In order to assess HER2 abnormalities during disease progression to muscle invasive disease, $\mathrm{pTa} / \mathrm{pT} 1$ and $\mathrm{pT} 2$ tumours from the same patient were compared. All patients had full clinical follow-up (age, date of diagnosis, cystoscopic followup, tumour stage and grade and survival). Ethical approval was obtained for these studies. $(5 \mu \mathrm{g})$ Sections of formalin-fixed paraffin tissue were cut onto sialinised slides and baked at $56^{\circ} \mathrm{C}$ overnight. All representative TCCs analysed had one section stained with haematoxylin and eosin (H\&E), and were restaged and regraded by a specialist urological pathologist (KMG). The pathologist rejected 52 tumours initially selected for the study because of the absence of detrusor muscle in either the pre- or postinvasive tumour. In order to be accepted for the study, both pre- and postinvasive tumours had to have detrusor muscle in both specimens.

\section{Fluorescence in situ hybridisation}

The FISH methodology was followed as outlined: tissue sections were dewaxed and rehydrated, then subject to pretreatments with $0.2 \mathrm{~N} \mathrm{HCL}$ for $20 \mathrm{~min}$ at room temperature, $8 \%$ sodium thiosulphate at $80^{\circ} \mathrm{C}$ for $30 \mathrm{~min}$, and $0.5 \%$ pepsin in $0.01 \mathrm{~N} \mathrm{HCL}$ for $26 \mathrm{~min}$ at $37^{\circ} \mathrm{C}$. Tissue sections were postfixed in $10 \%$ neutral buffered formalin at room temperature for $10 \mathrm{~min}$ before dehydration in ascending grades of alcohol and air drying. These steps were carried out on a VP2000 robotic pretreatment slide processor (Vysis, UK, Ltd). The tissue sections were assessed for the extent of tissue digestion (Watters et al, 2000). Tissue sections were denatured in $70 \%$ formamide, $2 \times$ SSC, $\mathrm{pH} 7-8$ at $72^{\circ} \mathrm{C}$ for $5 \mathrm{~min}$ on the Omnislide hybridisation module (Hybaid, UK, Ltd). Probes for the pericentromeric region of chromosome 17 (SpectrumGreen $^{\mathrm{TM}}$ ) and the locus specific probe for HER2 (SpectrumOrange $^{\mathrm{TM}}$ ) were used. For each section, $1 \mu \mathrm{l}$ of each probe was added to $7 \mu$ l hybridisation mix (50\% formamide, $2 \times$ SSC, $10 \%$ dextran sulphate) and $1 \mu \mathrm{l}$ deionised water and denatured in a water bath at $72^{\circ} \mathrm{C}$ for $5 \mathrm{~min}$ and then hybridised overnight at $37^{\circ} \mathrm{C}$. Posthybridisation washes were in $0.4 \times \mathrm{SSC}$, Nonidet $30, \mathrm{pH} 7$, at $72^{\circ} \mathrm{C}$ for $2 \mathrm{~min}$. The sections were mounted in $0.25 \mu \mathrm{g} \mathrm{ml}^{-1}$ DAPI antifade (Veactashield, UK) and viewed with a Leica DMLB microscope. A triple band pass filter block spanning the excitation and emission wavelengths of the SpectrumOrange ${ }^{\mathrm{TM}}$ and SpectrumGreen ${ }^{\mathrm{TM}}$ and DAPI was used in the analysis of the hybridisation. Image capture was achieved using a digital camera (Leica DC 200, Leica, UK).

\section{Fluorescence in situ hybridisation scoring}

Serially sectioned haemtoxylin- and eosin-stained tissue sections were first examined to localise areas of TCC. Fluorescence in situ hybridisation sections were then scanned at $\times 400$ magnification to localise the areas of interest. In total, three areas were identified and in each area 20 nuclei were assessed. Chromosome 17 copy number and HER 2 copy number were assessed for each of the 20 nuclei at $\times 1000$ magnification. An average chromosome 17 copy number and HER2/neu copy number was obtained totalling the number of signals over the 60 nuclei and dividing by the number of signals. Control sections of normal bladder and HER2/neu gene amplified breast tumours were included in each run. The values for disomy were derived from the analysis of normal bladder postmortem tissue, as previously assessed (Bartlett et al, 1998; Watters et al, 2000). The average HER2/neu copy number was $1.7( \pm 0.1)$ and hence a HER $2 /$ neu copy number greater than $2(1.7+3 \times$ s.d. $)$ was defined as 'increased'. The average chromosome 17 copy number was $1.7( \pm 0.06)$ and hence a polysomy 17 was defined as a chromosome 17 copy number greater than $1.88(1.7+3 \times$ s.d. $)$. Gene amplification was defined as an HER2/Chromosome 17 ratio of greater than 2 (Bartlett, 2001), based on the value used in breast cancer diagnostics.

\section{Immunohistochemistry}

Antigen retrieval was performed by placing the slides in a pressure cooker containing 11 of boiling water with $0.37 \mathrm{~g}(1 \times 10-3$ moles $)$ of ethylenediaminetetracetic acid (EDTA). The pressure cooker was placed in a microwave $(850 \mathrm{~W})$ for $13.5 \mathrm{~min}$, then the lid was removed and the slides were left to stand for another $20 \mathrm{~min}$. The slides were then loaded onto an automated machine (NEXUS II, Ventana USA) with a rotating slide carousel. The following reagents were added in sequence automatically by the machine (all steps were performed at $37^{\circ} \mathrm{C}$, and reagents were purchased prepacked): (1) $0.1 \mathrm{ml}$ of inhibitor (containing $1.1 \%$ hydrogen peroxide, which is metabolised by endogenous peroxidase), for $4 \mathrm{~min}$; (2) $100 \mu \mathrm{l}\left(0.63 \mathrm{~g} \mathrm{ml}^{-1}\right)$ of $\mathrm{CB} 11$ monoclonal primary antibody (IgG 1); (3) $0.1 \mathrm{ml}$ each of amplifier A (IgG heavy and light chains) and B (IgG heavy chains) for $8 \mathrm{~min}$. This binds to the previously bound primary antibody, increasing the number of antibodies at the site of the antigen, thereby increasing staining intensity; (4) $0.1 \mathrm{ml}$ of biotinylated secondary antibody (IgG) for $8 \mathrm{~min}$; (5) $0.1 \mathrm{ml}$ of avidin-HRPO conjugate (horseradish peroxidase), which binds to the biotin, for $8 \mathrm{~min}$; (6) $0.1 \mathrm{ml}$ of diaminobenzidine (DAB) for $8 \mathrm{~min}$. This chromagen produces a brown precipitate at the sites of the avidin-biotin reaction; (7) $0.1 \mathrm{ml}$ of copper sulphate to enhance the brown precipitate; (8) $0.1 \mathrm{ml}$ of haematoxylin and $0.1 \mathrm{ml}$ of bluing agent containing lithium carbonate to stain the nuclei blue. The slides were then dehydrated through graded alcohols and mounted and fixed with xylene and DPX. Normal bladder tissue controls and breast cancers with HER2/neu gene amplification and strong protein overexpression were used as controls in each run.

\section{Scoring}

Representative areas were identified from the H\&E sections and corresponding areas were scored using a conventional light 
microscope. Only membrane staining was scored, with cytoplasmic staining being ignored. A 4-point scale was used: ' 0 ' if there was no membrane staining, ' 1 ' if there was weak membrane staining in at least $10 \%$ of cells, ' 2 ' if there was moderate membrane staining in at least $10 \%$ of cells, ' 3 ' if there was strong membrane staining in at least $10 \%$ of cells.

\section{RESULTS}

\section{Patients}

The average age of the patients was 71.3 years (range $43-92$ ) and there were 20 male and five female patients. The average time to progression from preinvasive disease was 20.6 months (range 290). There was one postoperative death, eight patients were still alive and $16(16 / 25,64 \%$ had died from their disease. The average survival from the time of the diagnosis of muscle-invasive disease to death was 9.9 months (range 1-57). In the majority of cases detrusor muscle invasion was preceded by either a pT1G3 (13 out of 26 cases) or a pTaG2 (10/26 cases) tumour. Tables $1 \mathrm{a}$ and $1 \mathrm{~b}$ give the stages and grades of the tumours, the FISH and IHC results as well as the times to progression.

\section{Fluorescence in situ hybridisation}

The average HER2/neu copy number for the preinvasive tumours was 3.34 (range $1.73-18.30$ ) and 3.48 for the postinvasive tumours (range 1.90-8.50), and these were not statistically different $(P=0.086)$. Overall, 19 out of $25(76 \%)$ of the preinvasive and 23 out of $25(92 \%)$ of the postinvasive tumours had an increased HER2/neu copy number. The average chromosome 17 copy number for the preinvasive group was 2.58 (range 1.74-3.68) and 3.16 (range $1.62-8.48$ ) for the postinvasive group, and again these were not statistically different $(P=0.067)$. Overall 23 out of $25(92 \%)$ of the preinvasive group and 24 out of $25(96 \%)$ of the postinvasive group were polysomic for chromosome 17. The average $H E R 2 /$ chromosome 17 ratio in the preinvasive group was 1.34 and 1.17 in the postinvasive group; these values were not statistically different $(P=0.31)$. These results are summarised in Table 2. Two tumours out of both the pre- and postinvasive groups were amplified for HER2/neu, representing three patients in total. The stages and grades of these four tumours are given in Table 4.

\section{Immunohistochemistry}

In all, 19 (19 out of $25,76 \%$ ), of the preinvasive tumours and 13 $(52 \%)$ of the postinvasive tumours were 'positive' for HER2/neu protein overexpression and therefore six (six out of 25, 24\%) of the preinvasive and $12(48 \%)$ of the postinvasive tumours were 'negative' (Table 3).

\section{DISCUSSION}

Contemporary models of bladder TCC progression suggest that tumours of a higher stage and grade have accumulated more genetic changes (Simon et al, 1998). It is thought that genetic changes occur in sequence, such that certain genetic changes are more common in pT2 compared with $\mathrm{pTa} / \mathrm{T} 1$ tumours (Sauter $e$ al, 1998). In the study by Simon et al (1998), the overall average number of genetic aberrations in pT1 tumours was 9.8, in comparison with 3.7 in pTa tumours, a statistically significant difference $(P<0.01)$. The authors concluded that these two tumour groups are very different, both genetically and in terms of clinical behaviour, with the pT1 tumours more likely to progress to detrusor muscle-invasive disease than the pTa tumours, which did not progress. In the present study, there were $11 \mathrm{pTa}$ and $14 \mathrm{p} \mathrm{T} 1$ tumours (Tables 1a and 1b), but in contrast to the study by Simon
Table Ia The HER2/chromosome 17 ratio, HER2 copy number, chromosome 17 copy number, $\mathrm{HC}$ score and time to progression in months for all 26 tumour pairs

\begin{tabular}{|c|c|c|c|c|c|}
\hline $\begin{array}{l}\text { Patient } \\
\text { number }\end{array}$ & $\begin{array}{c}\text { HER2/ } \\
\text { chromosome } \\
\text { I7 ratio }\end{array}$ & $\begin{array}{c}\text { Chromosome } \\
17 \text { copy } \\
\text { number }\end{array}$ & $\begin{array}{c}\text { HER2 } \\
\text { copy } \\
\text { number }\end{array}$ & $\begin{array}{l}\text { IHC } \\
\text { score }\end{array}$ & $\begin{array}{l}\text { Time to } \\
\text { progression } \\
\text { (months) }\end{array}$ \\
\hline $\mathrm{la}$ & 1.06 & 2.75 & 2.89 & '3' & 13 \\
\hline Ib & 1.25 & 3.48 & 4.33 & '3' & \\
\hline $2 a$ & 1 & 1.74 & 1.73 & '3' & 62 \\
\hline $2 b$ & 1.17 & 1.93 & 2.25 & '2' & \\
\hline $3 a$ & 1.21 & 3.86 & 4.68 & '2' & 9 \\
\hline $3 b$ & 1.16 & 3.41 & 4.03 & ' ’’ & \\
\hline $4 a$ & 1.13 & 2.33 & 2.6 & ' 3 ' & 3 \\
\hline $4 b$ & 1.51 & 3.19 & 4.97 & '3' & \\
\hline $5 a$ & 1.02 & 1.83 & 1.87 & '3' & 38 \\
\hline $5 b$ & 1.06 & 1.81 & 1.9 & '0' & \\
\hline $6 a$ & 1.09 & 1.98 & 2.14 & '3' & 2 \\
\hline $6 b$ & 1.5 & 2.13 & 3.17 & '3' & \\
\hline $7 a$ & 1.09 & 3.49 & 3.83 & '3' & 3 \\
\hline $7 b$ & 0.98 & 2.96 & 2.93 & '2' & \\
\hline $8 a$ & 0.82 & 3.28 & 2.61 & '3' & 19 \\
\hline $8 b$ & 1 & 8.48 & 8.5 & '3' & \\
\hline $9 a$ & 0.95 & 2.22 & 2.09 & '2' & 32 \\
\hline $9 b$ & 1.07 & 2.08 & 2.21 & ‘’ & \\
\hline $10 \mathrm{a}$ & 1.06 & 2.77 & 2.9 & '2' & 10 \\
\hline $10 b$ & 0.83 & 2.51 & 2 & '0' & \\
\hline $1 \mathrm{la}$ & 0.92 & 2.35 & 2.15 & '3' & 4 \\
\hline $11 \mathrm{~b}$ & 0.96 & 2.63 & 2.49 & '3' & \\
\hline $12 \mathrm{a}$ & 0.91 & 2.7 & 2.47 & '3' & 42 \\
\hline $12 b$ & 0.98 & 3.15 & 3.07 & ' 3 ' & \\
\hline $13 a$ & 0.78 & 3.26 & 2.5 & '3' & 12 \\
\hline $13 b$ & 0.88 & 2.78 & 2.4 & '3' & \\
\hline $14 a$ & 0.96 & 3.39 & 3.24 & '3' & 17 \\
\hline $14 b$ & 0.9 & 3.43 & 3.08 & '3' & \\
\hline $15 a$ & 2.18 & 2.9 & 6.33 & ' 3 ' & 6 \\
\hline $15 b$ & 2.09 & 3.01 & 6.2 & '3' & \\
\hline $16 a$ & 1.14 & 2.43 & 2.74 & 'I’ & 5 \\
\hline $16 b$ & 1.48 & 4.7 & 7.04 & '0' & \\
\hline $17 \mathrm{a}$ & 8.07 & 2.3 & 18.3 & '3' & 26 \\
\hline $17 b$ & 1.45 & 2.26 & 3.17 & ' 0 ' & \\
\hline $18 a$ & 0.96 & 1.91 & 1.82 & $0^{\prime}$ & 3 \\
\hline $18 b$ & 2.02 & 1.62 & 3.2 & '0' & \\
\hline $19 a$ & 1.11 & 2.26 & 2.54 & '0' & 3 \\
\hline $19 b$ & 1.06 & 3.89 & 4.07 & '0' & \\
\hline $20 a$ & 0.98 & 1.97 & 1.93 & ' 0 ' & 90 \\
\hline $20 b$ & 1.33 & 3.43 & 2.58 & '0' & \\
\hline $21 a$ & 1.02 & 1.91 & 1.94 & '0' & 10 \\
\hline $2 \mathrm{lb}$ & 0.99 & 2.01 & 1.98 & '0' & \\
\hline $22 a$ & 1.04 & 2.13 & 2.21 & '2' & 55 \\
\hline $22 b$ & 1.06 & 3.69 & 3.79 & '3' & \\
\hline $23 a$ & 1.05 & 2.2 & 2.33 & '3' & 6 \\
\hline $23 b$ & 1.06 & 2.16 & 2.29 & '3' & \\
\hline $24 a$ & 1.07 & 3.62 & 3.8 & '3’' & 15 \\
\hline $24 b$ & 0.96 & 2.98 & 2.86 & '0' & \\
\hline $25 a$ & 0.95 & 1.84 & 1.75 & ' 0 ' & 31 \\
\hline $25 b$ & 0.69 & 5.5 & 3.83 & '0' & \\
\hline
\end{tabular}

et al, all the tumours in this study progressed to detrusor muscle invasion. Table 2 compares the pTa tumours with the pT1 tumours in terms of HER2 copy number, chromosome 17 copy number and protein overexpression, demonstrating that they were not statistically different. This suggests that the subgroup of pTa tumours that are genetically different from pT1 tumours, as suggested by Simon et al, are those that are unlikely to progress to pT2 disease. However, in the present study, all the $\mathrm{pTa} / \mathrm{pT} 1$ tumours progressed to pT2 disease and as such had a completely different clinical course. Hence, in terms of tumour progression, tumour stage and grade (Table 4) appear to be less important than the actual genetic changes that a tumour has accumulated. This study suggests that 
Table Ib Stage and grade distribution of the 25 pairs of tumours

\begin{tabular}{|c|c|c|c|c|c|c|c|c|}
\hline & G3 pT2 & G2 pT2 & G3 pT4 & G2 pTa & G3 pTI & GI pTa & GI pT I & G2 pTI \\
\hline
\end{tabular}

The table illustrates that most (23/2523/26) of the postinvasive tumours were G3 pT2, and there were II pTa and I4 pTI tumours in the preinvasive group.

Table 2 Mean HER2 copy number, chromososme 17 copy number and HER2/chromosome 17 copy ratio in the pTa and p TI tumours

\begin{tabular}{|c|c|c|c|}
\hline & $\begin{array}{c}\text { Mean HER2 } \\
\text { copy number (range) }\end{array}$ & $\begin{array}{l}\text { Mean chromosome } \\
\text { I7 copy number (range) }\end{array}$ & $\begin{array}{c}\text { Mean } H E R 2 / \text { chromosome } 17 \\
\text { ratio (range) }\end{array}$ \\
\hline $\begin{array}{l}\mathrm{pTa} \\
(n=\mid \mathrm{I}) \\
\mathrm{pTI} \\
(N=\mid 5)\end{array}$ & $\begin{array}{l}3.34 \\
(1.7-18.3) \\
3.53 \\
(1.9-8.5)\end{array}$ & $\begin{array}{l}2.58 \\
(1.74-3.68) \\
3.16 \\
(1.62-8.48)\end{array}$ & $\begin{array}{l}1.34 \\
(082-2.18) \\
1.17 \\
(0.91-8.07)\end{array}$ \\
\hline
\end{tabular}

There was no difference in the rates of polysomy $17(P=0.21)$, HER2/neu copy number $(P=0.34)$ or HER2/chromosome $17(P=0.44)$ ratio between the pTa and pT tumours.

Table 3 Values for the HER2 immunohistochemistry results

\begin{tabular}{lcccc}
\hline & '0' & 'I+' & '2+' & '3+' \\
\hline Preinvasive & 5 & 1 & 4 & 15 \\
Postinvasive & 10 & 2 & 2 & 11 \\
\hline
\end{tabular}

The HER2 immunohistochemistry results for the 25 pairs of patients. Both ' $2+$ ' and ' $3+$ ' were considered positive and ' 0 ' and ' $1+$ ' were considered negative. In total, 19 out of $2576 \%$ of the preinvasive tumours were positive. The level of protein overexpression was less in the postinvasive tumours ( 13 out of $26,50 \%$ ).

Table 4 Stage and grade details of the four gene amplified tumours, together with FISH results

\begin{tabular}{lccc}
\hline $\begin{array}{l}\text { Tumour } \\
\text { stage/grade }\end{array}$ & $\begin{array}{c}\text { HER2 } \\
\text { copy number }\end{array}$ & $\begin{array}{c}\text { Chromosome I7 } \\
\text { copy number }\end{array}$ & $\begin{array}{c}\text { HER2I } \\
\text { chromosome I7 }\end{array}$ \\
\hline G2 PTa & 6.33 & 2.99 & 2.18 \\
G3 PT2 & 6.2 & 3.01 & 2.09 \\
G3 PT1 & 18.3 & 2.3 & 8.07 \\
G3 PT2 & 3.22 & 1.6 & 2.01 \\
\hline
\end{tabular}

The tumours with HER2/chromosome 17 ratios of 2.18 and 2.09 are from the same patient, suggesting that gene amplification is present before the onset of muscle invasion and persists. The preinvasive G3 pTI tumour with the highest level of amplification had a postinvasive HER2/chromosome 17 ratio of 1.45. The postinvasive G3 PT2 tumour with borderline gene amplification of 2.01 had a preinvasive HER2/chromosome 17 ratio of 0.96 .

those tumours that progress to pT2 disease have acquired significant HER2/neu abnormalities before muscle invasion. Oncogene activation is thought to occur late, and most genetic changes are thought to occur before disease progression (Tsao et al, 2000). It therefore appears that in tumours that progress to pT2 disease have already acquired HER2/neu abnormalities that occur before the onset of detrusor muscle invasion.

Gene amplification rates were low, being present in $8 \%$ of both tumour groups, a value similar to previously published rates of 7 and 9\% (Sauter et al, 1993; Underwood et al, 1995). The results are also similar to those recently published by our group where polysomy $c-m y c$ and $C C N D 1$ rates were higher than gene amplification rates (Watters et al, 2002). Polysomy has been shown to occur independently of tumour polyploidy and is not only chromosome specific but also closely related to tumour progression (Watters et al, 2002).

High levels of HER2/neu protein overexpression were also observed, with rates of 76 and $52 \%$ present in pTa/T1 and pT2 tumours, respectively. These values were not significantly different $(P=0.06)$, again suggesting that high level protein overexpression occurs before tumour progression. It has been suggested that either transcriptional or post-transcriptional mechanisms are responsible for the observed difference between protein overexpression and gene amplification. This phenomenon has also been observed in breast cancers. In one study, 22 out of $79(29 \%)$ of breast cancers had HER2/neu protein overexpression without HER2/neu gene amplification (Farabegoli et al, 1999). In a previous study by Sauter et al (1993), 89\% of bladder tumours with HER2/ neu protein overexpression did not have gene amplification, results which are similar to the present study. Transcription rates, and hence HER2/neu protein expression are controlled by nuclear concentrations of the transcription factors such as GATA-3 and OB2-1 (Shiga et al, 1993; Hollywood and Hurst, 1995). Higher levels of such transcription factors, even in the absence of gene amplification, result in increased HER2/neu protein overexpression. Stomach cancer cell lines SNU-1 and SNU-16 have similar HER2/neu transcription rates with similar mRNA concentrations, but the SNU-1 cells express the HER2/neu protein at a higher level than the SNU-16 cells. This is due to preferential translation of the mRNA from the SNU-1 cells (Bae et al, 2001).

Anti-HER2/neu therapy has been used to treat breast cancers in a clinical setting with encouraging results. Herceptin is a monoclonal antibody directed against the HER2/neu protein, which has an antimitotic and antiangiogeneic effect on tumours cells. In breast cancer, response rates have been highest in tumours that have strong protein overexpression (which are also gene amplified). Overall response rates of $50 \%$ have been observed (Slamon et al, 2001). Furthermore, synergism has been demonstrated between Herceptin and conventional chemotherpeutic agents like cisplatin (Baselga, 2001). The high rates of strong $($ ' $3+$ ') protein overexpression rates in the $\mathrm{pTa} / \mathrm{T} 1$ tumours $60 \%$, together with the high rates of polysomy 17 and increased HER2/neu copy number suggests that Herceptin might also be of value in the treatment of TCC. In particular, the application of anti-HER2/neu therapy to pTa or pT1 tumours that are most likely to progress to pT2 disease, based upon the presence of increased HER 2 copy number, polysomy 17 and increased HER2/ neu protein overexpression might lower the rate of disease progression. 


\section{REFERENCES}

Bae CD, Juhnn YS, Park JB (2001) Post-transcriptional control of c-erb B2 overexpression in stomach cancer cells. Exp Mol Med 37(1): 15-19

Bartlett JMS, Adie L, Watters AD, Going JJ, Grigor KM (1999) Chromosomal aberrations in transitional cell carcinoma that are predictive of disease outcome are independent of polyploidy. $\mathrm{Br} \mathrm{J} \mathrm{Urol}$ Int 84(7): $775-779$

Bartlett JMS, Watters AD, Ballantyne SA, Going JJ, Grigor KM, Cooke TG (1998) Is chromosome 9 loss a marker of disease recurrence in transitional cell carcinoma of the urinary bladder? Br J Cancer 77(12): $2193-2198$

Bartlett JM, Goint JJ, Mallon EA, Reeves JR, Stanton P, Richmond J, Donald B, Ferrier R, Cooke TG (2001) Evaluating her 2 amplification and overexpression in breast cancer. J path 195(4): 422-428

Baselga J (2001) Clinical trials of Herceptin. Eur J Cancer 37: s18-s24

Coombs LM, Pigott DA, Sweeney E, Proctor AJ, Eydmann ME, Parkinson C, Knowles MA (1991) Amplification and over-expression of c-erbB-2 in transitional cell carcinoma of the urinary bladder. $B r J$ Cancer 63(4): $601-608$

Ellis IO, Dowsett M, Bartlett J, Walker R, Cooke T, Gullick W, Gusterson B, Mallon E, Lee PB (2000) Recommendations for HER2 testing in the UK. I Clin Pathol 53(12): $890-892$

Farabegoli F, Ceccarelli C, Santini D, Taffurelli M, Marrano D, Trere D, Derezini M (1999) C-ERB-B2 overexpression in amplified and nonamplified breast carcinoma samples. Int J Cancer 84(3): 273-277

Hollywood DP, Hurst HC (1995) Targeting gene transcription: a new strategy to down regulate c-erbB2 expression in mammary carcinoma. $\mathrm{Br}$ J Cancer 71: $4753-4757$

Li B, Kanamaru H, Noriki S, Fukuda M, Okada K (1998) Numeric aberration of chromosome 17 is strongly correlated with p53 overexpression, tumour proliferation and histopathology in human bladder cancer. Int J Urol 5(4): 317-323

McCann A, Dervan PA, Johnston PA, Gullick WJ, Carney DN (1990) CerbB-2 oncoprotein expression in primary human tumours. Cancer 65(1): $88-92$

Mellon JK, Lunec J, Wright C, Horne CH, Kelly P, Neal DE (1996) C-erbB-2 in bladder cancer molecular biology, correlation with epidermal growth factor receptors and prognostic value. J Urol 155(1): 321 - 326

Olayioye MA, Neve RM, Lane HA, Hynes NE (2000) The ErbB signalling network: receptor heterodimerization in development and cancer. $E M B O$ J 19(13): 3159-3167

Reznikoff CA, Sarkar S, Knut PJ, Burger MS, Newton MA (2000) Genetic alterations and biological pathways in Human bladder cancer pathogenesis. Urol Oncol 5: 191-203

Sauter G, Mihatsch MJ, Gudat F, Waloman F (1998) Pussycats and baby tigers: non-invasive (pTa) and minimally invasive (pT1) bladder carcinomas are not the same. J Pathol 185(4): 339-341
Sauter G, Moch H, Moore D, Carroll P, Kerschmann R, Chew K et al (1993) Heterogeneity of erbB-2 gene amplification in bladder cancer. Cancer Res 53(10 Suppl): 2199-2203

Shiga K, Shiga C, Sasano H, Miyazaki S, Yamamoto T, Haysshi N, Mori S (1993) Expression of C-erb B2 in human oesophageal carcinoma cells: over-expression correlated with gene amplification or with GATA-3 transcription factor expression. Anticancer Res 13(5): 1293-1301

Simon R, Burger H, Brinkschmidt C, Bocker W, Hertle L, Terpe HJ (1998) Chromosomal aberrations associated with invasion in papillary superficial bladder cancer. J Path 185(4): 345-351

Skinner DG, Daniels JR, Russell CA, Lieskovsky G, Boyd SD, Nichols P, Kern W, Sakanoto J, Krailo M, Groshen S (1991) The role of adjuvant chemotherapy following cystectomy for invasive bladder cancer: a prospective comparative trial. J Urol 145(3): 459-464

Slamon DJ, Leyland-Jones B, Shak S, Fuchs H, Paton V, Bajamonde A, Fleming T, Eirrman W, Pegram M, Baselga J, Norton L (2001) Use of chemotherapy plus a monoclonal antibody against HER2 for metastatic breast cancer that over-expresses HER2. $N$ Eng J Med 344: 783-792

Tsao J-L, Yatabe Y, Markl IDC, Haiyan K, Jomes PA, Shibata D (2000) Bladder cancer genotype stability during clinical progression. Genes Chromosomes Cancer 29: 26-32

Tzahar E, Waterman H, Chen X, Levkowitz G, Karunagaran D, Lavi S, Lavis S, Ratzkin BJ, Yarden Y (1996) A hierarchical network of interreceptor interactions determines signal transduction by Neu differentiation factor/neuregulin and epidermal growth factor. Mol Cell Biol 16(10): $5276-5287$

Underwood M, Bartlett J, Reeves J, Gardiner DS, Scott R, Cooke T (1995) CerbB-2 gene amplification: a molecular marker in recurrent bladder tumors? Cancer Res 55(11): 2422-2430

Van Der Meijden A, Sylvester R, Collete L, Bono A, Ten Kate F (2000) The role and impact of pathology review on stage and grade assessment of stages Ta and T1 bladder tumours: a combined analysis of 5 EORTC trials. J Urol 164(5): $1933-1937$

Vogel CL, Cobleigh MA, Tripathy D, Gutheil JC, Harris LN, Fehrenbacher L, Slamon DJ, Murphy M, Novotny WF, Burchmore M, Shak S, Stewart SJ (2001) First line Herceptin monotherapy in metastatic breast cancer. Oncology 61: $37-42$

Watters AD, Ballantyne SA, Going JJ, Grigor KM, Bartlett JM (2000) Aneusomy of chromosomes 7 and 17 predicts recurrence of transitional cell carcinoma of the urinary bladder. BJU 85(1): $42-47$

Watters AD, Latif Z, Forsyth A, Dunn I, Underwood MA, Grigor K, Bartlett JMS (2002) Genetic aberrations of $c-m y c$ and CCND1 in the development of invasive bladder cancer. $\mathrm{Br} J$ Cancer 87: 654-658

Wright C, Mellon K, Neal DE, Johnston P, Corbett IP, Horne CH (1990) Expression of c-erbB-2 protein product in bladder cancer. $\mathrm{Br} \mathrm{J}$ Cancer 62(5): $764-765$ 